\title{
A Comparative Study between the Use of Role Play and Discussion Method in Teaching Speaking Ability
}

\author{
John Pahamzah, Syafrizal Syafrizal, Nurhaedah Gailea, Masrupi \\ Masrupi, and Enung Mulyati, jhon.pahamzah@untirta.ac.id, Universitas \\ Sultan Ageng Tirtayasa, Indonesia
}

\begin{abstract}
This research is aimed to find out whether role play and discussion methods were able to enhance students' progress on speaking skills. The researchers also attempt to investigate whether role play or discussion method better enhancing the students' speaking performance after the teaching-learning process conducted. To achieve these aims, the quasi-experimental research design is employed. The data were gathered from 60 students of twelfth grade in one of the vocational high schools in Pandeglang, Banten. The sample of the research were taken randomly by using lottery and the students were divided into experimental and control groups. Some instruments like pre-test - post-test were employed to collect the data. At the end of the study, many advantages were found to improve the students' speaking skill including vocabulary, grammar, and pronunciation aspect. Both groups indicated to experience improvement, but the experimental group showed more advanced enhancement indicated by their achieving to reach the 'good' category in speaking. While none of the students from the control group could get that. Conclusively, students taught by the discussion method show more improvement with 19.93 as their mean score. While students by role-play method have 13.73 as their mean score. It is significantly different from both methods indicated by the significance value score of 0.14 which is less than 0.05 . Hence, the discussion method is more effective than the role-play method in improving students' speaking ability. For that reason, it is recommended for teachers to use discussion method to improve students' speaking comprehension.
\end{abstract}

Keywords - speaking, teaching speaking, speaking strategies, role-play method, discussion method

\section{A. INTRODUCTION}

The aim of focusing on teaching speaking in vocational high school is to prepare the students to enter the world of work. There were many reasons when one study English, first they want to be part of International network, secondly, the students' speaking ability especially English becomes one of the core competencies required by many recruiters. Good communication skill is completely required once the students graduate from school. Meanwhile, graduates who do not have excellent communication will suffer badly in this era of competition. McKay et.al. (2011) mentions that there are many reasons why someone chooses to study English; Access to jobs and communication.

More specifically, Eramust (2015) explained that the ultimate aim of learning a language is to communicate, and speaking is one of the central elements of communication. However, teaching English as a second language is not always easy, especially in improving students' speaking ability. Students are often worried about making mistakes, fearful of criticism or simply being shy. Not only have that, but the accent of the mother 
tongue also becomes one of the obstacles in pronouncing English words. More than that, a lack of vocabulary also resists many students to speak up in English classes.

Until now, there has been no perfect method of teaching English, especially for speaking. So, teachers have very eclectic applications of approaches to their teaching in combination with their experiences when trying to explain certain speaking materials in front of the class. Teachers are many times encouraged to find interactive methods that might stimulate students to speak English in the classroom.

The method of teaching-learning process should be related to their daily activities or issues related to them, then they can feel more motivated to speak. Besides, topics chosen in implementing certain methods should meet their interests, so they at least can participate more actively in speaking classroom. Hence, the researchers tries to experiment with two methods in attempting to improve students' speaking ability significantly; role-play and discussion method (Guérin et al. 2017).

Brookfield and Preskill (1999) it is one of the ways people can improve their speaking ability by talking to each other. For that reason, the researchers assumes that discussion may significantly effective in improving students' speaking skills. Also, discussion requires class participation that may motivate students to speak more.

Roleplay is considered to be an effective method in improving students' skills as in educational context. Booth (2007); Moore (2015) described the role as a viable activity that engages students cognitively and affectively to work together to resolve issues. By implementing the method, the researchers expects that there would be positive impacts on students' speaking ability.

Language is first and foremost a spoken and not a written entity. Human beings talked and listened to ages before there was anything for them to read. This is why it is said that in the long history of the human race, the invention of writing was an event of yesterday. Hussain (2018) highlighted speaking as a major skill in communication. Moreover, as emphasized by Murphy (2014), English is widely learned as a second language and is an official language of the United Nations, of the European Union, and many other worlds and regional international organizations. As time progresses, Eramust (2015) stated that the need for learning English as a second language of many people has been growing dramatically all over the world.

Along with that, speaking is considered as the most important skill among four skills (listening, speaking, reading, and writing) because people who know a language are referred to as speakers of that language (Ur 2000). The statements above mean using a language is more important than just knowing about it because there is no point in knowing a lot about the language if you can't use it (Boch and Piolat 2005). Together with that, different approaches to teaching English have come into being to serve as a guide to teaching English methodologically and effectively as well.

Ewa (2014) defines discussion is a diverse body of teaching techniques that emphasize participation, dialogue, and two-way communication. The benefits of discussion include helping students develop critical understanding, self-awareness, appreciation for diverse perspectives, and the ability to take action. It is along with the theory of Brookfield (1999) that discussion method aims to develop critical, informed understanding, enhance self-critique, foster appreciation for diverse views, and help people take informed action. While specifically in an educational context, Brookfield and Preskill (2012) state that discussion as a method of teaching has many complexities that teachers may not conclude

228 | IJET| Volume. 9, Issue 2. December 2020

Copyright 2020 John Pahamzah, Syafrizal Syafrizal, Nurhaedah Gailea, Masrupi Masrupi, and Enung Mulyati are licensed under Creative Commons Atrribution- ShareAlike 4.0 International License. 
prematurely that this method is not working in a classroom. However, announcing to students that you have decided to use discussion will not in and of itself unleash a hunger for learning and communication. One of the most common mistakes made by teachers experimenting with discussion is to assume if it does not immediately transform their classroom, it should be abandoned.

As instructors, many teachers have had the experience of teaching courses where students participate frequently the classes flow well, and all involved feel like the course was a success. On the other hand, most of us have also had quite the opposite experience, where it is a regular struggle to get students to ask questions and participate in discussions. Student engagement, a broader, more encompassing term, which consists of four factors (skills, participation/interaction, emotional, and performance) is becoming increasingly important in higher education (Mosleh and Baba 2013)

Many teaching approaches such as role-play, problem-solving and pair work, etc., have the potential to involve the students in the learning process longer that indirectly promotes critical thinking dispositions like open-mindedness, fair-mindedness, perseverance and empathy among students (Bradford et al. 2006). Specifically, role play is considered as a viable activity that engages students cognitively and affectively to work together to resolve issues (Stacy, Moore, and Cain 2015; Booth 2007). Moreover, Eramust (2015) mentioned that role-playing is considered to be a technique of cooperative method in learning. Not so much different, Oatey (2008) defined role-play as 'a social or human activity in which participants "take on" and "act out" specified "roles" often within a predefined social framework or situational blueprint (a "scenario")'.

Ur (2000) explained that teachers use the term role-play to refer to several different activities, ranging from simple dialogues promoted by specific information on role cards, to more complex simulations that pass through several stages. Several advantages have been claimed for role-playing as a fluency activity if it is performed in pairs or groups rather than one group acting in front of the class. It encourages participation of a large number of students. If it is based on real-life situations, both transactional and interpersonal, it is a useful rehearsal for these. Some students find role play easier than free discussion.

\section{B. METHOD}

The population of this study was 120 students. To determine the sample of this study, the sampling technique used was purposive sampling. To determine the sample of this study, the sampling technique used was randomized sampling. Purposive sampling is a sampling technique where the researchers selects units to be sampled based on their knowledge and professional judgment. The reserachers took two classes as the sample of the study. They were class XI TKJ 1 and X1 TKJ 2. There were 30 students from each class were decided to be the sample of this study. The first 30 students from class XI TKJ 1 participated as experimental group and the other 30 students taken from class XI TKJ 2 participated as a control group. This decision of the two classes by considering the number of students got involved in the classes.

The researchers applies a quantitative approach by using a Quasi-Experimental design. In implementing the experimental design, the researchers employs a comparative method to gain more comprehensive and reliable results of data analysis.

There are four stages of conducting the research, (1) preliminary observation, (2) designing method, (3)method implementation.

i. Preliminary Research: Before designing the research, the researchers firstly observe the students' speaking skill and choose the respondents of the research. 
ii. Designing research: In this phase, the researchers analyzes the result of the direct observation and design the proper method to develop the students' speaking ability.

iii. Method Implementation: In this stage, the researchers implements two experiments to the experimental groups by using two methods; role-play and discussion method. While the control group do not get any treatment.

Things related to the data source to the data analysis technique would be elaborated as follows.

i. Data Source: In this study, the researchers employs pre-test, post-test, and direct observation as an instrument to gather all data needed.

ii. Data Acquisition Technique: Data acquisition technique will be elaborated here.

\section{Direct Observation}

Observation was conducted to gain prior information about the students' speaking ability and how to pick the right methods to overcome their obstacles in speaking English

2. Pre-test

Pre-test was given to both the experimental and control group before the different treatments provided to both groups. There were two pre-tests provided at two different times since the researchers used two different methods of teaching. It was intended to gain information about the students' initial speaking ability.

\section{Post-test}

Post-test was given to both the experimental and control group after the different treatments provided to both groups. The post-test conducted had no difference with the pre-test to gain more accurate information about how the treatment affects students' speaking ability. There were two post-tests provided. The first post-test given was aimed to find out the students' progress of speaking skills after the role-play method as the first treatment conducted to the experimental group.

In examining the students' ability for the first treatment, the teacher asked students to be paired. Each pair then performed a random topic provided by the researchers that they should express asking and giving suggestions as the material taught. The second post-test employed was aimed to figure out the students' improvement of speaking skills after the discussion method as the second treatment implemented to the experimental group. In examining the students' ability for the first treatment, the teacher asked students to be paired. Each pair then performed a random topic provided by the researchers that they should include giving opinion expressions as the material taught.

The data needed which were collected were further analyzed to find out the result of this study. The data analysis included the scoring technique, data analysis on instrument tryout, data analysis on the pre-test and post-test result.

Scoring for the speaking test in this research is based on Language Assessment: Principle and Classroom Practices by Douglas Brown (2004). Following the scoring, there were five- level to describe the students' speaking ability: Excellent, Good, Fair, Limited and Weak. The highest score for this research was 25, and the lowest was 5. For real educational reports, the teacher would then multiply all scores with 4 to gain 100 as the perfect score. It also would ease the teacher in adjusting with KKM as standard score for the students.

To find out whether there was significantly different between the experimental and control group, the data of the pre-test - post-test from both groups had to be analyzed. The analyzing processes in this study intended to use the t-test formula. However, before performing the $t$ - test formula, the data was ensured to meet the conditions required. The requirements of using the t-test were as follows: the data are interval-ratio scale, the underlying distributions are bell- shaped (normally distributed), the observations are independent, and the variance of the two groups must be homogenous (Davis 2009). Besides, are licensed under Creative Commons Atrribution- ShareAlike 4.0 International License. 
the conditions required of using the dependent t-test were similar to the independent $\mathrm{t}$-test, except the requirement that the observations are independent. The assumption for the dependent t-test was the observations were not independent, but the observations were correlated or dependent (Davis 2009).

\section{Testing Normal Distribution}

In the research, the present study used Kolmogrov-Smirnov's formula to analyze the normal distribution. The table data output from SPSS 24.00 for windows. The following formula was used to calculate the Normal Distribution of the data:

$$
\begin{aligned}
& \left.\mathrm{f}(\mathrm{x})=1 / \sqrt{[2 \pi \sigma]^{2}}\right) e^{\left([-(x-\mu)]^{2} /[2 \sigma]^{2}\right.} \\
& \text { Note: } \\
& \mu=\text { mean of } \mathrm{x} \\
& \sigma=\text { Standard deviation of } \mathrm{x} \\
& \pi=3.14159 \\
& \mathrm{e}=2.71828
\end{aligned}
$$

These steps were taken to test the normal distribution:

Looking at the hypothesis

$\mathrm{Ho}=$ The distribution of the scores are normally distributed

$\mathrm{H} 1=$ The distribution of the scores are not normally distributed

Analyzing the normal distribution by using Kolmogrov-Smirnov formula in SPSS 24.0 for windows

Comparing the level of significance to test the hypothesis. If the result is more than the level of significance (0.05), the null hypothesis is accepted, the score is normally distributed.

\section{Testing Variance Homogeneity}

In analyzing the variance homogeneity, the present study used Levene's formula in SPSS 24.00. These are the steps taken to test variance homogeneity:

Stating the hypothesis;

$\mathrm{Ho}=$ the variance of the experimental and control group is homogeneous

$\mathrm{H} 1=$ the variance of the experimental and control group are not homogeneous

Analyzing the variance homogeneity using SPSS 24.0 for windows;

Comparing the level of significant value to test the hypothesis. If Levene's test is significant at $\mathrm{p}<0.05$, it means that the null hypothesis is incorrect and the variances are significantly different. But if Levene's is non-significance at $p>0.05$. it means that the variance is approximately equal (Davies and Elder 2004)

\section{Independent T-test}

The primary purpose of the T-test is to determine whether the means of two groups for scores differ to a statistically significant degree. There are some requirements of the data which must be considered before conducting a t-test. First, the data should be measured in the form of an interval or ratio. Second, the data should be homogeneous or formed in the same type. Third, the data should have a normal distribution.

The procedures of t-test computation were as follows:

Stating the hypothesis 
$\mathrm{Ho}=$ there is no difference between the post-test mean for the experimental group and control group.

$\mathrm{H} 1=$ there is a significant difference between the post-test mean for both experimental and control group windows;

Finding the $\mathrm{t}$ value with independent sample test computation in SPSS 24.00 for

Comparing the significance value with the level of significance for testing hypothesis. If the significance value is less than the level of significance $(0.05)$, the null hypothesis is accepted. It means that the two groups are equivalent.

\section{RESULT AND DISCUSSION}

This research has still some ongoing process to be completed. Thus, only data from the questionnaire, written and oral test result that will be presented as follows:

i. Pre-test Result

The pre-test was conducted for experimental and control groups. The pre-test scores were analyzed to measure the students' initial ability in speaking for suggesting getting the treatment.

\section{1). Pre-test Result before Implementing Role Play Method}

\begin{tabular}{|c|c|c|c|c|c|}
\hline \multicolumn{6}{|c|}{ Descriptive Statistics } \\
\hline & \multicolumn{3}{|l|}{ Group } & Statistic & Std. Error \\
\hline \multirow[t]{12}{*}{ Pretest Roleplay } & \multirow[t]{12}{*}{ Control } & \multicolumn{2}{|l|}{ Mean } & 7.60 & .344 \\
\hline & & \multirow{2}{*}{$\begin{array}{l}95 \% \\
\text { Confidence } \\
\text { Interval for } \\
\text { Mean }\end{array}$} & $\begin{array}{l}\text { Lower } \\
\text { Bound }\end{array}$ & 6.90 & \\
\hline & & & $\begin{array}{l}\text { Upper } \\
\text { Bound }\end{array}$ & 8.30 & \\
\hline & & \multicolumn{2}{|c|}{$5 \%$ Trimmed Mean } & 7.56 & \\
\hline & & \multicolumn{2}{|l|}{ Median } & 7.50 & \\
\hline & & \multicolumn{2}{|l|}{ Variance } & 3.559 & \\
\hline & & \multicolumn{2}{|c|}{ Std. Deviation } & 1.886 & \\
\hline & & \multicolumn{2}{|l|}{ Minimum } & 5 & \\
\hline & & \multicolumn{2}{|l|}{ Maximum } & 11 & \\
\hline & & \multicolumn{2}{|l|}{ Range } & 6 & \\
\hline & & \multicolumn{2}{|c|}{ Interquartile Range } & 3 & \\
\hline & & \multicolumn{2}{|l|}{ Skewness } & .197 & .427 \\
\hline
\end{tabular}

232 | IJET| Volume. 9, Issue 2. December 2020

Copyright 2020 John Pahamzah, Syafrizal Syafrizal, Nurhaedah Gailea, Masrupi Masrupi, and Enung Mulyati are licensed under Creative Commons Atrribution- ShareAlike 4.0 International License. 


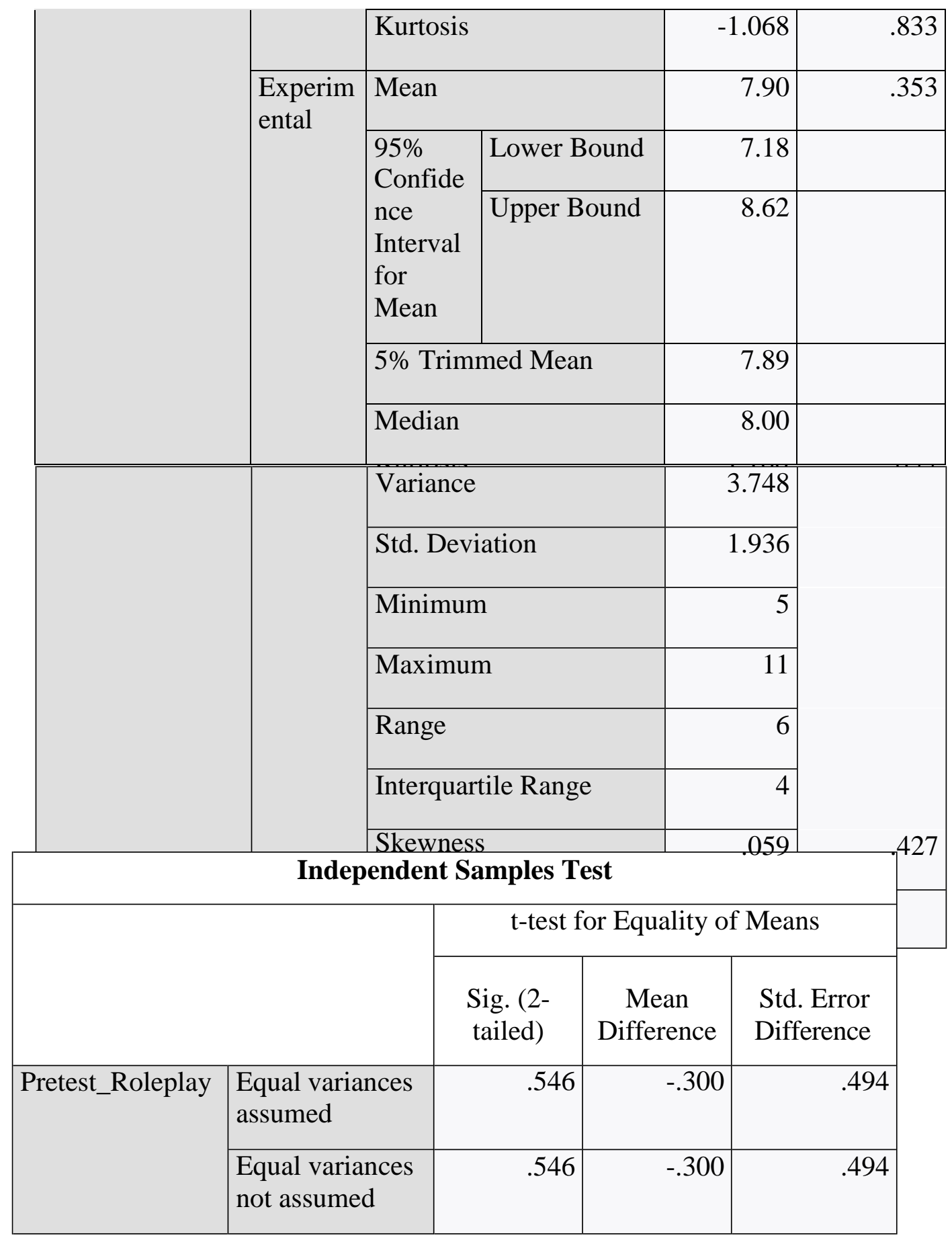

From the statistics table, the mean score of the control group is 7.6. While the mean score of the experimental group is 7.9. It can be said there is no significant difference in the first pre-test.

The null hypothesis was accepted because the difference was not significant, sig 2-tailed value $=0.546>0.05$. So, there was no significant difference between the pre-test score of the control and experimental group before treatment is provided.

\section{2). Pre-test Result before Implementing Discussion Method}




\begin{tabular}{|c|c|c|c|c|c|}
\hline \multicolumn{6}{|c|}{ Descriptive Statistics } \\
\hline & \multicolumn{3}{|l|}{ Group } & $\begin{array}{l}\text { Statist } \\
\text { ic }\end{array}$ & Std. Error \\
\hline \multirow{3}{*}{$\begin{array}{l}\text { Pretest } \\
\text { Discussion }\end{array}$} & \multirow[t]{3}{*}{ Control } & \multicolumn{2}{|l|}{ Mean } & 7.53 & .324 \\
\hline & & \multirow[t]{2}{*}{$\begin{array}{l}95 \% \text { Confidence } \\
\text { Interval for Mean }\end{array}$} & $\begin{array}{l}\text { Lower } \\
\text { Bound }\end{array}$ & 6.87 & \\
\hline & & & $\begin{array}{l}\text { Upper } \\
\text { Bound }\end{array}$ & 8.20 & \\
\hline & & \multicolumn{2}{|l|}{$5 \%$ Trimmed Mean } & 7.54 & \\
\hline & & \multicolumn{2}{|l|}{ Median } & 7.50 & \\
\hline & & \multicolumn{2}{|l|}{ Variance } & 3.154 & \\
\hline & & \multicolumn{2}{|l|}{ Std. Deviation } & 1.776 & \\
\hline & & \multicolumn{2}{|l|}{ Minimum } & 5 & \\
\hline & & \multicolumn{2}{|l|}{ Maximum } & 10 & \\
\hline & & \multicolumn{2}{|l|}{ Range } & 5 & \\
\hline & & \multicolumn{2}{|l|}{ Interquartile Range } & 3 & \\
\hline & & \multicolumn{2}{|l|}{ Skewness } & .020 & .427 \\
\hline & & \multicolumn{2}{|l|}{ Kurtosis } & -1.312 & .833 \\
\hline & \multirow{9}{*}{$\begin{array}{l}\text { Experime } \\
\text { ntal }\end{array}$} & \multicolumn{2}{|l|}{ Mean } & 7.90 & .353 \\
\hline & & \multirow[t]{2}{*}{$\begin{array}{l}95 \% \text { Confidence } \\
\text { Interval for Mean }\end{array}$} & $\begin{array}{l}\text { Lower } \\
\text { Bound }\end{array}$ & 7.18 & \\
\hline & & & $\begin{array}{l}\text { Upper } \\
\text { Bound }\end{array}$ & 8.62 & \\
\hline & & \multicolumn{2}{|l|}{$5 \%$ Trimmed Mean } & 7.89 & \\
\hline & & \multicolumn{2}{|l|}{ Median } & 8.00 & \\
\hline & & \multicolumn{2}{|l|}{ Variance } & 3.748 & \\
\hline & & \multicolumn{2}{|l|}{ Std. Deviation } & 1.936 & \\
\hline & & \multicolumn{2}{|l|}{ Minimum } & 5 & \\
\hline & & \multicolumn{2}{|l|}{ Maximum } & 11 & \\
\hline
\end{tabular}

$234 \mid$ IJET| Volume. 9, Issue 2. December 2020 are licensed under Creative Commons Atrribution- ShareAlike 4.0 International License. 


\begin{tabular}{|l|l|r|r|}
\hline Range & 6 & \\
\hline Interquartile Range & 4 & \\
\hline Skewness & .059 & .427 \\
\hline Kurtosis & -1.166 & .833 \\
\hline
\end{tabular}

From the statistics table, the mean score of the control group is 7.53. While the mean score of the experimental group is 7.9. Based on the mean score, it can be assumed that there is no significant difference in the pre-test scores before the teaching process started.

\begin{tabular}{|l|l|r|r|r|}
\hline \multicolumn{5}{|c|}{ Independent Samples Test } \\
\hline \multicolumn{2}{|c|}{} & \multicolumn{2}{|c|}{ t-test for Equality of Means } \\
\cline { 3 - 5 } \multicolumn{2}{|c|}{} & Sig. (2-tailed) & $\begin{array}{c}\text { Mean } \\
\text { Difference }\end{array}$ & $\begin{array}{c}\text { Std. Error } \\
\text { Difference }\end{array}$ \\
\hline $\begin{array}{l}\text { Pretest_Discuss } \\
\text { ion }\end{array}$ & $\begin{array}{l}\text { Equal variances } \\
\text { assumed }\end{array}$ & .448 & -.367 & .480 \\
\cline { 2 - 5 } & $\begin{array}{l}\text { Equal variances not } \\
\text { assumed }\end{array}$ & .448 & -.367 & .480 \\
\hline
\end{tabular}

The null hypothesis was accepted because the difference was not significant, sig 2-tailed value $=0.19>0.05$. So, there was no significant difference between the pre-test score of the control and experimental group before treatment is provided in giving opinion material.

\section{ii. Post-test Result}

The post-test was administered to check whether there was a difference in the experimental group who was treated by the role-play method as a treatment and control group who was not. The post-test scores between the experimental and control groups.

1). Post-test Result after Implementing Role Play Method

\begin{tabular}{|c|c|c|c|c|c|}
\hline \multicolumn{6}{|c|}{ Descriptives } \\
\hline & \multicolumn{3}{|l|}{ Group } & Statistic & Std. Error \\
\hline \multirow[t]{4}{*}{ Posttest_Roleplay } & \multirow[t]{4}{*}{ Control } & \multicolumn{2}{|l|}{ Mean } & 13.67 & .385 \\
\hline & & \multirow[t]{2}{*}{$\begin{array}{l}95 \% \text { Confidence } \\
\text { Interval for Mean }\end{array}$} & $\begin{array}{l}\text { Lower } \\
\text { Bound }\end{array}$ & 12.88 & \\
\hline & & & $\begin{array}{l}\text { Upper } \\
\text { Bound }\end{array}$ & 14.45 & \\
\hline & & \multicolumn{2}{|l|}{$5 \%$ Trimmed Mean } & 13.69 & \\
\hline
\end{tabular}

235 | IJET| Volume. 9, Issue 2. December 2020

Copyright 2020 John Pahamzah, Syafrizal Syafrizal, Nurhaedah Gailea, Masrupi Masrupi, and Enung Mulyati are licensed under Creative Commons Atrribution- ShareAlike 4.0 International License. 


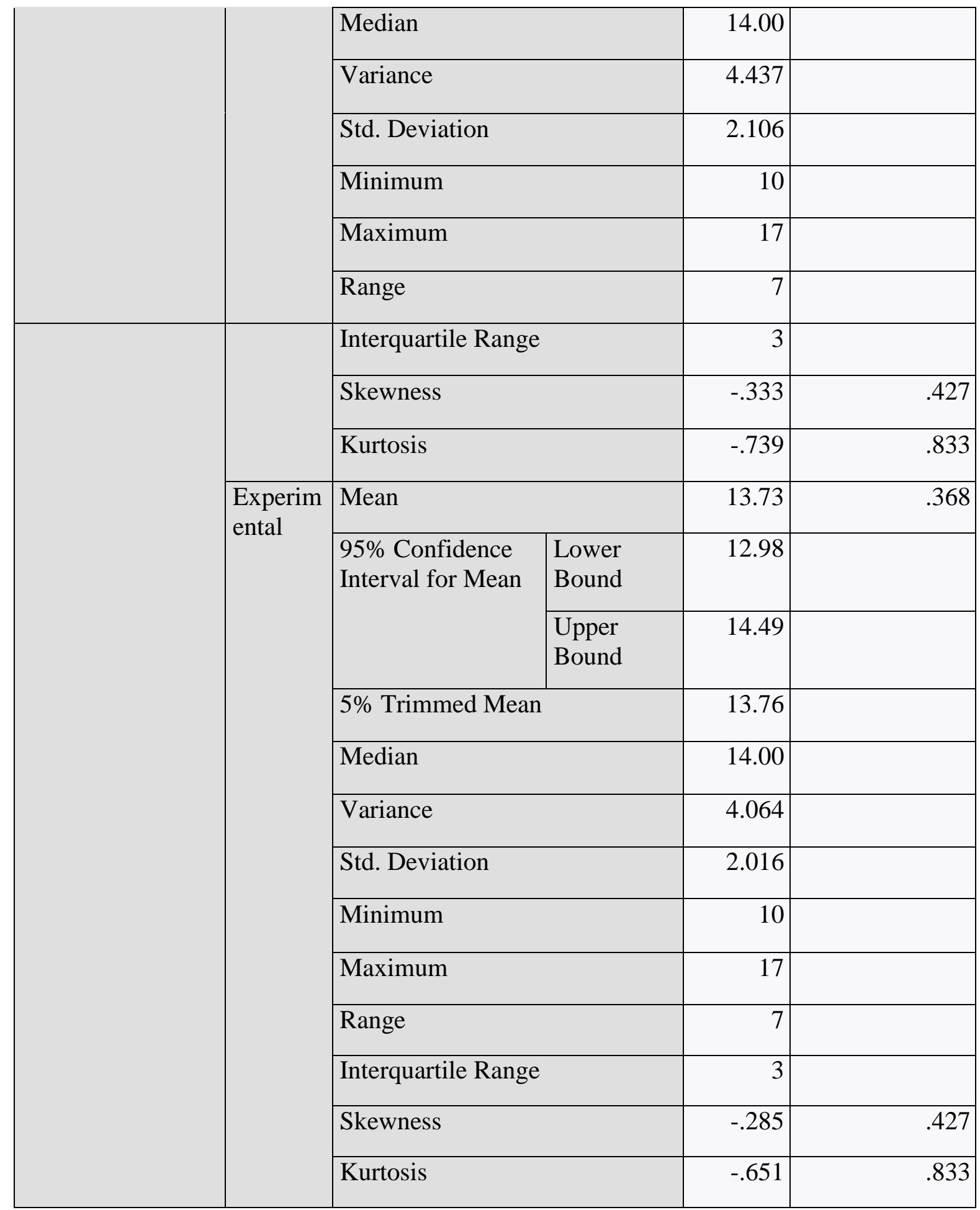

From the statistics table, the mean score of the control group is 13.67. While the mean score of the experimental group is 13.73. Based on the mean score, it can be assumed that there is no significant difference in the post-test scores after the teaching process started.

\begin{tabular}{|l|l|}
\hline \multicolumn{2}{|c|}{ Independent Samples Test } \\
\hline & t-test for Equality of Means \\
\hline
\end{tabular}
are licensed under Creative Commons Atrribution- ShareAlike 4.0 International License. 


\begin{tabular}{|l|l|r|r|r|}
\cline { 3 - 5 } \multicolumn{2}{l|}{} & Sig. (2-tailed) & $\begin{array}{l}\text { Mean } \\
\text { Difference }\end{array}$ & $\begin{array}{l}\text { Std. Error } \\
\text { Difference }\end{array}$ \\
\hline Posttest_Roleplay & $\begin{array}{l}\text { Equal variances } \\
\text { assumed }\end{array}$ & .901 & -.067 & .532 \\
\cline { 2 - 5 } & $\begin{array}{l}\text { Equal variances not } \\
\text { assumed }\end{array}$ & .901 & -.067 & .532 \\
\hline
\end{tabular}

The null hypothesis was accepted because the difference was not significant. It could be seen from the table above that the value of sig.2-tailed is 0.901 , meaning that $p>0.05$. Thus, it could be concluded that the role-play method implemented in the experimental group did not significantly improve the speaking ability of its students. It also answered the first research question in this study.

2). Post-test Result after implementing Discussion Method

\begin{tabular}{|c|c|c|c|c|c|}
\hline \multicolumn{6}{|c|}{ Descriptive Statistic } \\
\hline & \multicolumn{3}{|l|}{ Group } & Statistic & Std. Error \\
\hline \multirow[t]{14}{*}{ Posttest_Discussion } & \multirow[t]{13}{*}{ Control } & \multicolumn{2}{|l|}{ Mean } & 12.70 & .326 \\
\hline & & \multirow{2}{*}{$\begin{array}{l}95 \% \\
\text { Confidence } \\
\text { Interval for } \\
\text { Mean }\end{array}$} & $\begin{array}{l}\text { Lower } \\
\text { Bound }\end{array}$ & 12.03 & \\
\hline & & & $\begin{array}{l}\text { Upper } \\
\text { Bound }\end{array}$ & 13.37 & \\
\hline & & \multicolumn{2}{|c|}{ 5\% Trimmed Mean } & 12.69 & \\
\hline & & \multicolumn{2}{|l|}{ Median } & 13.00 & \\
\hline & & \multicolumn{2}{|l|}{ Variance } & 3.183 & \\
\hline & & \multicolumn{2}{|c|}{ Std. Deviation } & 1.784 & \\
\hline & & \multicolumn{2}{|l|}{ Minimum } & 10 & \\
\hline & & \multicolumn{2}{|l|}{ Maximum } & 16 & \\
\hline & & \multicolumn{2}{|l|}{ Range } & 6 & \\
\hline & & \multicolumn{2}{|c|}{ Interquartile Range } & 3 & \\
\hline & & \multicolumn{2}{|l|}{ Skewness } & .019 & .427 \\
\hline & & \multicolumn{2}{|l|}{ Kurtosis } & -1.125 & .833 \\
\hline & Experim & \multicolumn{2}{|l|}{ Mean } & 19.93 & .349 \\
\hline
\end{tabular}

237 | IJET| Volume. 9, Issue 2. December 2020 are licensed under Creative Commons Atrribution- ShareAlike 4.0 International License. 


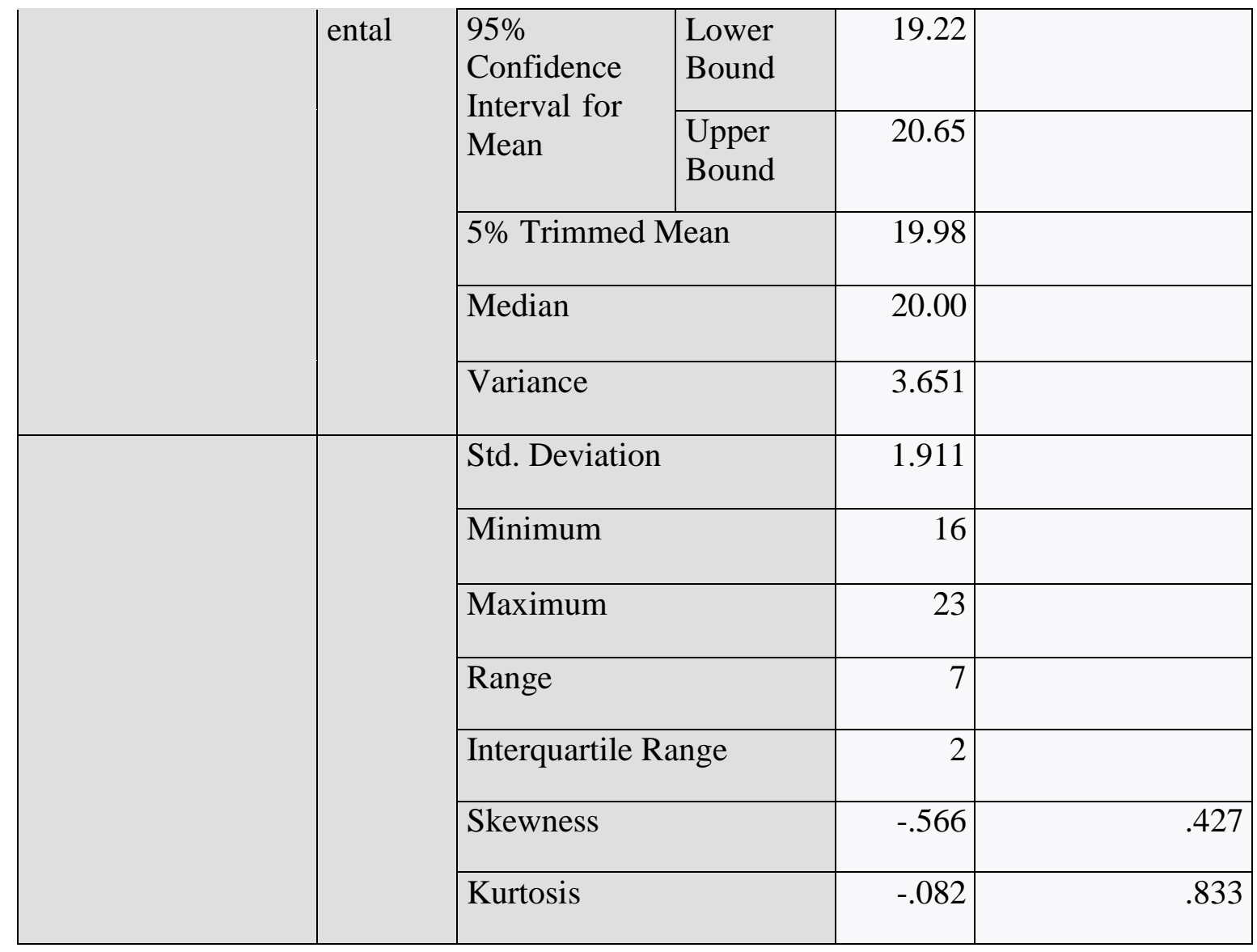

From the statistics table, the mean score of the control group is 12.7. While the mean score of the experimental group is 19.93. Based on the mean score, it can be assumed that there is a significant difference in the post-test scores after the experimental group discussed the teaching method.

\begin{tabular}{|l|l|r|r|r|}
\hline \multicolumn{5}{|c|}{ Independent Samples Test } \\
\hline \multicolumn{2}{|c|}{} & \multicolumn{2}{|c|}{ t-test for Equality of Means } \\
\cline { 3 - 5 } & $\begin{array}{c}\text { Sig. (2- } \\
\text { tailed) }\end{array}$ & $\begin{array}{c}\text { Mean } \\
\text { Difference }\end{array}$ & $\begin{array}{c}\text { Std. Error } \\
\text { Difference }\end{array}$ \\
\hline Posttest_Discussion & $\begin{array}{l}\text { Equal variances } \\
\text { assumed }\end{array}$ & .000 & -7.233 & .477 \\
\cline { 2 - 5 } & $\begin{array}{l}\text { Equal variances } \\
\text { not assumed }\end{array}$ & .000 & -7.233 & .477 \\
\hline
\end{tabular}

The null hypothesis was accepted because the difference was not significant. It could be seen from the table above that the value of sig.2-tailed is 0.000 , meaning that $p<0.05$. Thus, it could be concluded that the discussion method implemented to the experimental group in are licensed under Creative Commons Atrribution-ShareAlike 4.0 International License. 
teaching giving opinion material did significantly improve the speaking ability of its students.

\section{CONCLUSIONS}

It can be concluded that all aspects of speaking comprehension problems examined in this study influence the whole ability of the students in expressing their ideas verbally. However, if these factors are carefully put into consideration by teachers when teaching a foreign language, there is a higher possibility that the level of speaking comprehension of any given new language will be greatly increased. Besides, based on the findings of this research, it can be said that the use of certain teaching strategies can help the students in comprehending any aspect of speaking skill.

Highlighting role play and discussion method, the researchers sees the speaking improvement of the students is better when learning by the discussion method. Even though they also show improvement in learning by role-playing, their performance still less good than when they learn by the discussion method. Hence, based on this study, the discussion method is more effective in enhancing students' speaking ability than role-play method. Conclusively, to teach certain aspects of speaking skill requires creativity in modifying teaching methods, patience in motivating students, and passion to push students to speak more.

\section{E. REFERENCES}

Biech, Elaine. 2014. Bringing the Real World into the ClassroomBritish. London: Press of psychology.

Boch, Francoise, and Annie Piolat. 2005. "Note Taking and Learning A Summary of Research.” In Writing. Citeseer.

Booth, Sara. 2007. "Repositioning Research as Writing to Improve Student Learning." Australian Journal of Teacher Education 32, no. 4: 1.

Bradford, Stacey, Margaret E Shippen, Paul Alberto, David E Houchins, and Margaret Flores. 2006. "Using Systematic Instruction to Teach Decoding Skills to Middle School Students with Moderate Intellectual Disabilities." Education and Training in Developmental Disabilities, 333-43.

Brewster, Ellis, and Girard. 1992. The Primary English Teacher's Guide.

Brookfield, Stephen D, and Stephen Preskill. 2012. Discussion as a Way of Teaching: Tools and Techniques for Democratic Classrooms. John Wiley \& Sons.

Brookfield, Stephen, and Stephen Preskill. 1999. Discussion as a Way of Teaching: Tools and Techniques for University Teachers. McGraw-Hill Education (UK).

Brown Douglas, H. 2004. "Language Assessment: Principles and Classroom.” Practice. New York: Pearson Education, Inc.

Davies, Alan, and Catherine Elder. 2004. "The Handbook of Applied Linguistics Blackwell Publishing Blackwell Handbooks in Linguistics." Blackwell Handbooks in Linguistics 17: 866. https://doi.org/10.1002/9780470757000.ch7.

Davis, Barbara Gross. 2009. "Tools for Teaching. of The Jossey-Bass Higher and Adult Education Series.” San Francisco: John Wiley \& Sons. 
Ellis, and Levy. 2010. Panduan Untuk Peneliti Novice: Desain Dan Metode Penelitian Pengembangan. Prosedur Menginformasikan Pengawasan Ilmu Pengetahuan. Indonesia: InSITE.

Erasmust. 2015. Teaching the Blind Foreign Language.

Ferrell, Ka, Loana Mason, J Young, and J Cooney. 2006. "Forty Years of Literacy Research in Blindness and Visual Impairment," 1-33.

Finnegan, Ruth H. 2002. Communicating: The Multiple Modes of Human Interconnection. Psychology Press.

Franco, Gina M, Krista R Muis, Panayiota Kendeou, John Ranellucci, Lavanya Sampasivam, and Xihui Wang. 2012. "Examining the Influences of Epistemic Beliefs and Knowledge Representations on Cognitive Processing and Conceptual Change When Learning Physics." Learning and Instruction 22, no. 1: 62-77.

Guérin, Clément, Christophe Rigaud, Karell Bertet, and Arnaud Revel. 2017. "An OntologyBased Framework for the Automated Analysis and Interpretation of Comic Books' Images." Information Sciences 378: 109-30. https://doi.org/https://doi.org/10.1016/j.ins.2016.10.032.

Halliday, and Alexander Michael. 2009. "The Gloosy Ganoderm: Systemic Functional Linguistics and Translation." Chinese Translators Journal 1: 17-26.

Hussain, Shafaat. 2018. "Teaching Speaking Skills in Communication Classroom.” International Journal Of Media, Journalism And Mass Communications (Ijmjmc) 3: 14 21.

Ioannou-Georgiou, Sophie. 2003. Assessing Young Learners. Oxford University Press. Luoma, Sari. 2004. Assessing Speaking. Ernst Klett Sprachen.

Mao, Z C, and S L Yang. 2019. "International Perspectives on Teaching the Four Skills in ELT: Listening, Speaking, Reading, Writing." System 81: 214-16.

Mckenna, Michael C. 2011. "Informal Decoding Inventory."

Mohammed, Zainora, and Rokiah Omar. 2011. "Comparison of Reading Performance between Visually Impaired and Normally Sighted Students in Malaysia." British Journal of Visual Impairment 29, no. 3: 196-207.

Mosleh, Mogeeb a a, and Mohd Sapiyan Baba. 2013. "Overview of Traditional Note Taking." Educational Psychology Review, no. Cole 2005: 1-28.

Murphy, JM. 2014. "Intelligible, Comprehensible, Non-Native Models in ESL/EFL Pronunciation Teaching." Elsevier. https://www.sciencedirect.com/science/article/pii/S0346251X13001838.

Pawlak, Mirosław, and Ewa Waniek-Klimczak. 2014. Issues in Teaching, Learning and Testing Speaking in a Second Language. Springer.

Stacy, Elizabeth, Moore, and Jeff Cain. 2015. "Note-Taking and Handouts in The Digital Age.” American Journal of Pharmaceutical Education 79, no. 7.

Steinman, Bernard A, B J LeJeune, and B T Kimbrough. 2006. "Developmental Stages of Reading Processes in Children Who Are Blind and Sighted." Journal of Visual Impairment \& Blindness 100, no. 1:36-46. 
Tomlinson, Brian. 2003. Developing Materials for Language Teaching. A\&C Black.

Ur, Penny. 2000. "WA Course in Language Teaching: Practice and Theory." Foreign Language Teaching and Research Journal. are licensed under Creative Commons Atrribution- ShareAlike 4.0 International License. 